ISSN (online): 2722-2055 https://jurnal.umj.ac.id/index.php/ASSYIFA
AS-SYIFA: Jurnal Pengabdian dan Pemberdayaan Kesehatan Masyarakat

\title{
Edukasi Remaja Bebas Asap Rokok Sebagai Upaya Peningkatan Kesehatan di Masa Pandemi Covid-19 di Bantul
}

\section{Education of Smoke-Free Adolescent as an Effort to Improve Health in The Covid-19 Pandemic Period in Bantul}

\author{
1)*Marsiana Wibowo, ${ }^{2)}$ Yokas Siswanto, ${ }^{3)}$ Azmi Aji Pamungkas, ${ }^{4)}$ Gilang Andru \\ Firmansyah \\ ${ }^{122) 334)}$ Fakultas Kesehatan Masyarakat. Universitas Ahmad Dahlan \\ *Fakultas Kesehatan Masyarakat UAD Kampus 3, Jalan Prof. Dr. Soepomo, Janturan, Warungboto, \\ Umbulharjo, Yogyakarta, 55164 \\ *Email Korespondensi: marsiana.wibowo@ikm.uad.ac.id
}

\begin{abstract}
Abstrak
Penggunaan tembakau masih menjadi permasalahan kesehatan pelik di dunia. Perokok dewasa menyampaikan mereka memulai kebiasaannya semenjak remaja. Situasi pandemi COVID-19 menuntut kewaspadaan lebih termasuk meningkatkan imunitasnya agar tidak terinfeksi. Kebiasaan merokok meningkatkan risiko seseorang terpapar COVID-19 dan meningkatkan risiko keparahan penyakit akibat COVID-19. Tujuan dari pengabdian ini adalah meningkatkan pemahaman remaja tas risiko merokok dalam memperparah penyakit COVID-19 dan pemahaman dalam menyiapkan diri dan keluarga bebas asap rokok. Metode yang digunakan adalah blended learning untuk meningkatkan accessibility sasaran dalam menerima informasi di masa pandemi ini. Metode ceramah dan diskusi dilakukan melalui pertemuan langsung, zoom meeting, dan whatsapp. Pelaksana kegiatan bersama tim dari mahasiswa melaksanakan kegiatan kepada sasaran, yaitu remaja di Desa Turtomulyo, Kretek, Bantul.Hasil kegiatan menunjukkan adanya perubahan pemahaman remaja tentang bahanya merokok, namun belum ada keyakinan bahwa COVID-19 akan meningkatkan risiko remaja terinfeksi virus dan memperparah penyakitnya. Remaja juga belum siap menerapak rumah bebas asap rokok di lingkungan tempat tinggal mereka. Kegiatan edukasi remaja tentang bahaya merokok perlu dilakukan secara berkesinambungan. Diperukan peran aktif tokoh masyarakat setempat berkerja sama dengan Puskesmas dalam menggiatkan program remaja bebas asap rokok dan organisasi kemasyarakat yang membina keterampilan hidup sehat remaja.
\end{abstract}

Kata kunci : pandemi covid-19, remaja, tembakau, merokok

\begin{abstract}
Tobacco use is still a complex health problem in the world. Adult smokers say they started the habit as a teenager. The COVID-19 pandemic situation demands more vigilance, including increasing immunity so as not to become infected. Smoking habits increase a person's risk of being exposed to COVID-19 and increase the risk of disease severity due to COVID-19. This service aims to increase teenagers' understanding of the risk of smoking in exacerbating the COVID-19 disease and understanding in preparing themselves and their families to be smoke-free. The method used is blended learning to increase target accessibility in receiving information during this pandemic. The lecture and discussion method are carried out through in-person meetings, zoom meetings, and what apps. Implementing activities with a team of students carried out activities to the target, namely youth in Turtomulyo Village, Kretek, Bantul. The results of the activity showed a change in teenagers' understanding of the dangers of smoking, but there was no belief that COVID-19 would increase the risk of adolescents being infected with the virus and worsening the disease. Teens are also not ready to accept smoke-free homes in their neighbourhoods. Adolescent education activities about the dangers of smoking need to be carried out continuously. There is a need for the active role of local community leaders in collaboration with the Puskesmas in activating the smoke-free youth program and community organizations that foster youth healthy life skills.
\end{abstract}

Keyword : covid-19 pandemic, , tobacco, youth, smoking 
Volume. 2 No. 1 tahun 2020

Mei 2021 - November 2021
ISSN (online): 2722-2055 https://jurnal.umj.ac.id/index.php/ASSYIFA
AS-SYIFA: Jurnal Pengabdian dan Pemberdayaan Kesehatan Masyarakat

\section{Pendahuluan}

Penggunaan tembakau menjadi permasalahah global yang menyebabkan kematian di dunia. Merokok tembakau merupakan faktor risiko bagi enam dari delapan penyebab kematian dini, yaitu penyakit jantung iskemik, penyakit serebrovaskuler, infeksi saluran pernapasan bagian bawah, penyakit paru obstruktif kronik, TBC dan kanker trakea, bronkus dan paru-paru. Individu yang membangun perilaku merokok pada remaja awal juga meningkatkan risiko penyakit kardiovaskuler, penyakit pernapasan, dan kanker, dan mereka cenderung bereksperimen dengan alcohol dan obat-obatan lainnya (OECD/WHO, 2020). Sebagian besar pengguna tembakau dewasa saat ini mulai mengkonsumsi tembakau selama masa remaja yang berlanjut hingga dewasa (WHO, 2020b). Data WHO tentang prevalensi perokok remaja di Indonesia tahun 2019 menunjukkan (13-15 tahun) 19,2\% dan (16-17 tahun) 22,6\% (WHO, 2020a).

Beberapa penelitian mengemukakan bahwa merokok memiliki peluang memperparah penyakit COVID-19. Merokok merupakan faktor risiko pengembangan COVID-19 (Patanavanich and Glantz, 2020). Risiko keparahan COVID-19 berhubungan secara siknifikan dengan perilaku merokok aktif (Magfira and Helda, 2020)(Guo, 2020)(Berlin et al., 2020)(Berlin, 2021). Keseimbangan kuantitatif antara imunitas bawaan seseorang dengan dosis paparan kumulatif SARS-CoV-2 adalah faktor penting yang memutuskan apakah virus akan menembus saluran pernafasan bawah dan alveoli cukup dini, yaitu sebelum respon imun adaptif terbentuk, berkembang biak secara massif dan menyebabkan pneumonia parah(Matricardi, Dal Negro and Nisini, 2020). Masyarakat diharapkan dapat mengurangi kebiasaan merokok, menerapkan pola hidup sehat serta menjaga kebersihan tangan untuk mencegah penularan virus melalui tangan (Yunianto et al., 2020).

Kasus COVID-19 di Indonesia terus mengalami peningkatan. Daerah Istimewa Yogyakarta (DIY) sebagai provinsi dengan kasus rendah mengalami peningkatan jumlah kasus, diantaranya seperti di Kabupaten Bantul. Tercatat 7.402 kasus terkonfirmasi, 699 isolasi, dan 221 meninggal (Pemerintah Kabupaten Bantul, 2021). Pada Februari 2021, Kabupaten Bantul merupakan daerah zona risiko tinggi. Kapanewon Kretek menjadi salah satu Kabupaten dengan risiko penularan sedang, namun dengan skor batas menuju zona risiko penularan tinggi, yaitu 1,9 (Pemerintah Kabupaten Bantul, 2021). Namun, pemerintah menyarankan masyarakat tetap produktif di tengah pandemi dengan menerapkan protokol kesehatan ketat. Situasi ini menjadi arahan yang dipatuhi oleh pemegang kebijakan dan masyarakat di Kapanewon Kretek. Masyarakat berharap tetap bisa beraktifitas dengan menghasilkan pundi-pundi ekonomi di tengah pandemi. Situasi tersebut menjelaskan bahwa masyarakat di Kapanewon Kretek tetap beraktifitas seperti biasa. Masyarakat di Dusun Tirtomulyo pun juga berperilaku demikian, apalagi sebagian warga adalah pegawai yang sering berinteraksi dengan masyarakat diluar dusun. Risiko mereka tertular dari klaster perkantoran pun tinggi. Perilaku sehat sehari-sehari harus ditingkatkan. Namun demikian, edukasi terkait COVID-19 harus secara berulang dipaparkan kepada masyarakat. Isu tentang risiko perokok yang akan menurunkan imunitasnya dalam menghadapi virus corona ini belum disinggung. Masyarakat menganggap mereka sudah terlalu sering mendapatkan edukasi tentang COVID-19 dan mereka merasa bosan. Namun demikian, informasi terkait COVID-19 ini harus terus diberikan karena situasi pandemi terus mengalami update informasi. Persepsi tentang risiko perokok yang tidak rentan dalam memperparah keseriusan COVID-19 ini perlu diluruskan. Oleh karena itu, diperlukan intervensi kesehatan untuk 
ISSN (online): 2722-2055 https://jurnal.umj.ac.id/index.php/AS-
AS-SYIFA: Jurnal Pengabdian dan Pemberdayaan Kesehatan Masyarakat

meningkatkan pemahaman remaja atas risiko merokok dalam memperparah penyakit COVID-19 dan keterampilan dalam menyiapkan diri berhenti merokok.

\section{Metode}

Pengabdian masyarakat dilakukan di Desa Tirtomulyo, Kretek, Bantul. Sasaran kegiatan ini adalah remaja desa, dengan diwakili oleh remaja dari tiga dusun. Populasi kegiatan ini adalah seluruh remaja desa, sedangkan sampel kegiatan dipilih dengan teknik incidental, yaitu remaja yang hadir pada 3 hari tanggal yang telah ditentukan (22-25 Febrauri 2021). Kegiatan pengabdian kepada masyarakat dilaksanakan selama 3 hari dengan konsep pada tabel 1 .

Tabel 1. Konsep Kegiatan

\begin{tabular}{|c|c|c|c|}
\hline Tujuan & Program & Aktifitas & Evaluasi \\
\hline $\begin{array}{l}\text { Meningkatkan } \\
\text { pemahaman remaja atas } \\
\text { risiko merokok dalam } \\
\text { memperparah penyakit } \\
\text { COVID-19 }\end{array}$ & \multirow[t]{2}{*}{$\begin{array}{l}\text { Penyelenggaraan } \\
\text { penyuluhan } \\
\text { remaja bebas } \\
\text { asap rokok di } \\
\text { masa pandemi } \\
\text { COVID-19 }\end{array}$} & \multirow{2}{*}{$\begin{array}{l}\text { Ceramah dan } \\
\text { diskusi dengan } \\
\text { pendekatan: } \\
\text { 1. Langsung } \\
\quad \text { (tatap muka) } \\
\text { 2. Zoom meeting } \\
\text { 3. Diskusi melalui } \\
\text { whatsapps }\end{array}$} & \multirow[t]{2}{*}{$\begin{array}{l}\text { Tes lisan } \\
\text { (wawancara) }\end{array}$} \\
\hline $\begin{array}{l}\text { Meningkatkan } \\
\text { pengetahuan tentang } \\
\text { keterampilan dalam } \\
\text { menyiapkan diri berhenti } \\
\text { merokok }\end{array}$ & & & \\
\hline
\end{tabular}

Pencapaian tujuan kegiatan pengabdian kepada masyarakat dilakukan melalui sebuah program, yaitu edukasi kesehatan dengan sistem blended learning untuk meningkatkan pemahaman remaja atas risiko merokok dalam memperparah penyakit COVID-19 dan menyiapkan diri dan keluarga bebas asap rokok. Blended learning yang dimaksud adalah mengkombinasikan tiga jenis metode pembelajaran interaktif, yaitu zoom meeting, pertemuan langsung yang terbatas, dan diskusi melalui whatsapp. Sebagai upaya meningkatkan hasil, pelaksana menyiapkan power point dan video edukasi dimodifikasi dengan ceramah. Metode ini dipilih berdasarkan kemampuan akses saluran komunikasi dari sasaran kegiatan dengan mempertimbangkan situasi pandemi COVID-19 dan peraturan PPKM (Pemberlakuan Pembatasan Kegiatan Masyarakat) di Kabupanten Bantul. Pelaksana kegiatan melakukan evaluasi menggunakan observasi hasil percakapan dan diskusi melalui whatsapp dan kuesioner tidak terstruktur.

\section{Hasil Dan Pembahasan}

Dalam rangka meningkatkan pemahaman remaja atas risiko merokok dalam memperparah penyakit COVID-19, pelaksana kegiatan melakukan ceramah dengan alat bantu power point dan video. Pelaksana memaparkan informasi yang persuasif dengan sub topik: situasi terkini permasalahan tembakau pada remaja di Indonesia, kandungan zat kimia pada rokok dan asap tembakau, kerja nikotin dalam menjadikan seseorang adiksi terhadap tembakau, risiko merokok dalam memperparah COVID-19. Upaya yang dilakukan agar invididu dan keluarga bebas asap rokok, pelaksana pengabdian kepada masyarakat 
ISSN (online): 2722-2055 https://jurnal.umj.ac.id/index.php/AS-
AS-SYIFA: Jurnal Pengabdian dan Pemberdayaan Kesehatan Masyarakat

melakukan ceramah dan diskusi persuasif agar remaja terdorong untuk menyelenggarakan smoke free home di rumah/tempat tinggal.

Kegiatan ini dilaksanakan pada 22 - 25 Februari 2021 dengan metode blended learning. Metode ini dipilih sebagai bentuk penyesuaian akses dari sasaran kegiatan dan memperlancar komunikasi antara narasumber dan sasaran. Metode blended learning berupa pertemuan dengan zoom meeting, dilanjutkan dengan pertemuan langsung secara terbatas, dan diskusi dalam grup whatsapp. Memalui ketiga metode tersebut, kegiatan diikuti oleh 48 pemuda pemudi dari tiga dusun.

Hasil yang didapatkan oleh sasaran ketika setelah mendapatkan informasi adalah sasaran memahami dan setuju bahwa merokok berbahaya bagi kesehatannya. Edukasi secara online yang dilakukan melalui online meeting, power point, dan chat terbukti efektif meningkatkan pengetahuan (Sabarudin et al., 2020). Seluruh peserta mengatakan setuju bahwa merokok akan merugikan kesehatan baik bagi laki-laki maupun perempuan, paru-paru perokok tidak lebih sehat dari bukan perokok, nikotin akan memberikan dampak bagi perokok seperti menjadikan perokok kecanduan. Mereka juga setuju bahwa mereka akan menjauhi orang-orang rentan seperti perempuan dan anak-anak serta lansia ketika merokok.

Namun demikian fakta yang menyatakan bahwa merokok dapat meningkatkan risiko terpapar COVID-19 serta memperparah penyakit akibat COVID-19 belum sepenuhnya dipercaya oleh sasaran. Situasi ini ditunjukkan dengan salah satu komentar peserta dalam diskusi whatsapp berikut:

"maafkan kami bu.. masih ngeyel dengan jaman kuno. Semoga kami bisa mengurangi rokok kami (sambil dilampiri bungkus rokok, korek api, dan segelas teh)"

Diskusi kami di pagi hari tentang perilaku merokok mendapat sambutan komentar dari remaja:

"ro ngrokok ora le ngopi? (sambil merokok tidak yang minum kopi?" dan mendapat sahutan dari yang lain "ahaha.. iya dong"

Percakapan tersebut membuktikan bahwa remaja sudah memahami akan bahaya rokok, namun demikian mereka masih belum bisa lepas dari merokok. Kebiasaan merokok ini merupakan salah satu penghambat penerapan Kawasan Tanpa Rokok (Monica and Pambudi, 2021). Studi lain menunjukkan bahwa terdapat peningkatkan jumlah perokok remaja di masa pandemic COVID-19. Hal ini dikarenakan keluangan waktu remaja yang lebih banyak sehingga mereka lebih banyak "nongkrong" dan merokok bersama teman sebaya (Dea Naresawari et al., 2020). Remaja merasa merokok merupakan bagian dari aktifitas sehari-hari dan belum mempedulikan dampak kesehatan akibat merokok walau sampai pada kematian, seperti kutipan percakapan berikut:

"Wong rejeki pati.. wes dicatet ro malaikat.. mati kui ora iso ditolak, ora iso dinyang. Kan wes dterjadwal berarti. Mung awak e dewe je kora reti. Pasrah. Sumeleh, sareh, ora jireh (rejeki kematian dicatat oleh malaikat, mati itu tidak bisa disangkal, tidak bisa ditawar. Benar bahwa semua sudah diatur. Hanya kita sendiri yang tidak tahu. Pasrah, tidak takut) 
ISSN (online): 2722-2055 https://jurnal.umj.ac.id/index.php/AS-
AS-SYIFA: Jurnal Pengabdian dan Pemberdayaan Kesehatan Masyarakat

Melalui percakapan-percakapan tersebut, dibuktikan bahwa belum ada perubahan yang siknifikan dari perilaku merokok remaja. Remaja masih ingin terus mencoba, membersamai teman-teman sebaya, dan belum mendalami bahanya merokok terhadap metabolism tubuhnya (Dea Naresawari et al., 2020). Faktor-faktor ekstrinsik seperti teman, orang tua, dan iklan rokok berhubungan dengan perilaku merokok remaja (Tristanti, 2016). Melalui percakapan yang dilakukan di whatsapp, sangat tampak remaja lebih ringan dalam melontarkan gurauan, celotehan, pendapat, dan pengalaman pribadinya tentang perilaku merokoknya dibandingkan dengan pertemuan langsung. Dalam pertemuan zoom meeting dan pertemuan langsung, tidak banyak remaja yang berkomentar serta menceritakan pengalamannya. Penggunaan aplikasi whatsapp berpengaruh siknfikan dalam meningkatkan pengetahuan (Aziz, Kosasih and Lukman, 2019). Selain itu, konten tentang perilaku merokok di media sosial berpengaruh terhadap perilaku merokok remaja (Kusuma, Amiruddin and Saleh, 2020). Keterbatasan interaksi dengan remaja dalam kegiatan pengabdian kepada masyarakat ini menjadikan tidak mampu mempengaruhi kepedulian terhadap diri sendiri dalam meningkatkan kesehatannya dengan tidak merokok sehingga mereka belum siap diajak untuk menerapkan smoke free home di tempat tinggal mereka.

Namun demikian, terdapat masukan yang diterima oleh pelaksana kegiatan berupa diadakannya kegiatan serupa dengan tema lingkungan bebas asap rokok dan berhenti merokok sekarang juga. Hal ini menunjukkan bahwa remaja sebenarnya membutuhkan edukasi berkelanjutan untuk membebaskan remaja dari asap rokok dan menjadikan keluarga dan lingkungan bebas asap rokok.

\section{Kesimpulan Dan Saran}

Remaja memilii pemahaman yang baik tentang bahaya merokok namun pemahaman remaja terhadap risiko merokok dalam memperparah penyakit COVID-19 belum berubah. Remaja belum siap dalam menerapkan Smoke Free Home. Oleh karena itu edukasi remaja bebas asap rokok perlu menjadi perhatian khusus oleh tokoh masyarakat dan lembaga terkait seperti puskesmas, serta memperluas jangkauan program Smoke Free Home hingga Desa Tirtomulyo, Kapanewon Kretek

\section{Ucapan Terima Kasih}

Ucapan terima kasih kami sampaikan kepada Desa Tirtomulyo, Kretek, Bantul dan Lembaga Penelitian dan Pengabdian Masyarakat Universitas Ahmad Dahlan yang memberikan dukungan dalam menyelenggarakan kegiatan ini.

\section{Daftar Pustaka}

Aziz, A. R., Kosasih, C. E. and Lukman, M. (2019) 'Pengaruh Pemberian Informasi Kesehatan Berbasis Aplikasi Whatsapp terhadap Remaja di Sekolah Mengengah Atas', Al-Asalmiya Nursing: Journal of Nursing Sciences, 8(1), pp. 8-16. Available at: http://jurnal.alinsyirah.ac.id/index.php/keperawatan (Accessed: 11 March 2021).

Berlin, I. et al. (2020) 'COVID-19 and Smoking', Nicotine \& Tobacco Research, 22(9), pp. 1650-1652. doi: 10.1093/ntr/ntaa059.

Berlin, I. (2021) 'Risk of COVID-19 and smoking', Heart, 107(2), p. 170. doi: 10.1136/heartjnl-2020-318311.

Dea Naresawari, A. et al. (2020) ANALISIS PENGGUNA ROKOK DI MASA PANDEMI 
Volume. 2 No.1 tahun 2020

Mei 2021 - November 2021
ISSN (online): 2722-2055 https://jurnal.umj.ac.id/index.php/ASSYIFA

AS-SYIFA: Jurnal Pengabdian dan Pemberdayaan Kesehatan Masyarakat

COVID-19 DI KECAMATAN NOGOSARI Universitas Duta Bangsa Surakarta, Prosiding HUBISINTEK. Available at: http://ojs.udb.ac.id/index.php/HUBISINTEK/article/view/981 (Accessed: 11 March 2021).

Guo, F. R. (2020) 'Active smoking is associated with severity of coronavirus disease 2019 (COVID-19): An update of a meta-analysis', Tobacco Induced Diseases. International Society for the Prevention of Tobacco Induced Diseases. doi: 10.18332/TID/121915.

Kusuma, N. P., Amiruddin, R. and Saleh, L. M. (2020) 'Hubungan Media Sosial Dengan Awareness (Kesadaran) Bahaya Rokok Pada Siswa Sma Di Kota Makassar', Jurnal Kesehatan Masyarakat Maritim, 3(1). doi: 10.30597/jkmm.v3i1.10283.

Magfira, N. and Helda (2020) 'Correlation between adult tobacco smoking prevalence and mortality of Coronavirus Disease-19 across the world', medRxiv, p. 2020.12.01.20241596. doi: 10.1101/2020.12.01.20241596.

Matricardi, P. M., Dal Negro, R. W. and Nisini, R. (2020) 'The first, holistic immunological model of COVID-19: Implications for prevention, diagnosis, and public health measures', Pediatric Allergy and Immunology. Blackwell Publishing Ltd, pp. 454-470. doi: 10.1111/pai.13271.

Monica, R. and Pambudi, A. (2021) 'Implementasi Kebijakan Kawasan Tanpa Rokok Di Kota Manado', JURNAL POLITICO, 10(4), pp. 129-140. Available at: http://journal.student.uny.ac.id/ojs/index.php/adinegara/article/viewFile/8934/8588 (Accessed: 13 March 2019).

OECD/WHO (2020) 'Tobacco', in Health at a Glance: Asia/Pacific 2020: Measuring Progress Towards Universal Health Coverage. Paris: OECD Publishing. doi: https://doi.org/10.1787/2c5c9396-en.

Patanavanich, R. and Glantz, S. A. (2020) 'Smoking is associated with COVID-19 progression: A meta-analysis', Nicotine and Tobacco Research. Oxford University Press, pp. 1653-1656. doi: 10.1093/ntr/ntaa082.

Pemerintah Kabupaten Bantul (2021) Update Harian COVID-19 - Page 2 - BANTUL SIAGA COVID-19, Pemerintah Kabupaten Bantul. Available at: https://corona.bantulkab.go.id/category/update/page/2/ (Accessed: 9 March 2021).

Sabarudin et al. (2020) 'Efektivitas Pemberian Edukasi secara Online melalui Media Video dan Leaflet terhadap Tingkat Pengetahuan Pencegahan Covid-19 di Kota Baubau', Jurnal Farmasi Galenika (Galenika Journal of Pharmacy) (e-Journal), 6(2). doi: 10.22487/j24428744.2020.v6.i2.15253.

Tristanti, I. (2016) 'Remaja dan Perilaku Merokok', Prosiding The 3rd University Research Colloqium (URECOL) 2016.2 Available at: https://publikasiilmiah.ums.ac.id/xmlui/handle/11617/6772 (Accessed: 18 March 2019).

WHO (2020a) Global Youth Tobacco Survey, WHO. Available at: https://cdn.who.int/media/docs/default-source/searo/tobacco/global-youth-tobaccosurvey/indonesia-gyts-2019-factsheet-(ages-13-15)-(draft)---revised---6-162020.pdf?sfvrsn=477996b8_2.

WHO (2020b) The Tobacco Atlas: Prespectives from the WHO South-East Asia Region. First Edit, World Health Organization, Regional office for South-East Asia. First Edit. World 
AS-SYIFA: Jurnal Pengabdian dan Pemberdayaan Kesehatan Masyarakat

Health Organization, Regional office for South-East Asia. Available at: http://dx.doi.org/10.1016/j.cirp.2016.06.001\%0Ahttp://dx.doi.org/10.1016/j.powtec.201 6.12.055\%0Ahttps://doi.org/10.1016/j.ijfatigue.2019.02.006\%0Ahttps://doi.org/10.101 6/j.matlet.2019.04.024\%0Ahttps://doi.org/10.1016/j.matlet.2019.127252\%0Ahttp://dx. doi.o.

Yunianto, A. et al. (2020) 'Determining Community Lifestyle in Sumatra Island during COVID-19 Pandemic Time', Asian Pac. J. Health Sci. doi: 10.21276/apjhs.2020.7.4.13. 
